\title{
Static strength characteristics (MOR and MOE) of Australian Pinus ponderosa wood from plantation: a comparison of green, dry and re-wet specimens - a Technical Note
}

\author{
Dr Mihai Daian (corresponding author) \\ The University of Melbourne, 500 Yarra Blvd., Richmond, 3121, Victoria, \\ Australia \\ Tel.: +61431660887 \\ e-mail: mdaian@unimelb.edu.au
}

Prof. Voichita Bucur

CSIRO Australia, Clayton, Victoria, Australia

Assoc. Prof. Barbara Ozarska

The University of Melbourne, 500 Yarra Blvd., Richmond, 3121, Victoria, Australia

Dr Georgiana Daian

Forestworks Australia, 559A Queensberry Street, North Melbourne, 3051, Victoria, Australia

\begin{abstract}
:
The aim of this preliminary study is to determine the mechanical characteristics of Pinus ponderosa from mature-age Australian plantation (80 years old) in relation to three parameters: modulus of rupture (MOR) and modulus of elasticity (MOE) in bending, and density. The strength test was carried out on two groups of heartwood specimens: juvenile wood and mature wood. The specimens were studied in green state, dry (kiln dried at $12 \%$ moisture content) and re-saturated (50-60\% moisture content) state.

The comparison of the Pinus ponderosa' modulus of elasticity and modulus of rupture average values with Pinus radiata and Pinus loblolly values from Australia and New Zealand was done so that the aptitude of Pinus ponderosa of Australian origin for industrial purposes could be roughly established.
\end{abstract}

Keywords: mechanical properties, Australian plantation, Pinus ponderosa, wood, testing 


\section{Introduction}

Pinus ponderosa or Western Yellow pine is native from Western part of North America and is mainly found in regions extending from British Columbia to California. In Australia small quantities are grown in plantations, some of them established 80 years ago.

Bootle (1986) noted that Western Yellow pine wood is a lightweight, stable, easy to work, durable and is recognized as suitable for joinery, mouldings, furniture, toys making, pattern making and cooperage. It is not recommended however for outdoor or in ground applications.

Kretschmann (2010) reported some data on modulus of rupture (MOR) and modulus of elasticity (MOE) of Pinus ponderosa wood of American origin. To the best of our knowledge there is no data in the literature related to Pinus ponderosa from Australian plantations.

The aim of this study was to determine MOE and MOR in static bending tests of Pinus ponderosa wood originated from 80 years old Australian plantations.

The tests were performed on specimens at three moisture content conditions: green wood, dry wood (12\% moisture content) and re-saturated wood. These three conditions have been selected as they represent the current industrial utilization of this species such as in saw mills for green, in furniture industry, for dry, and in industrial drying process for re-saturated wood. Densities of the specimens were also determined.

\section{Sample preparation and experimental setup}

The trial consisted of $25 \mathrm{logs}$ of 80 years old Pinus ponderosa with a diameter varying from $30 \mathrm{~cm}$ to $45 \mathrm{~cm}$. The specimens have been prepared in accordance with ASTM D143-09 and Australian test method (Mack 1979). The specimen size was: 35 x 35 x 525mm. Three groups of samples have been selected for testing in green condition, in dry condition and in re-saturated condition. 26 samples have been cut from juvenile and mature zone of each log. The samples for testing in dry condition have been conditioned for $12 \%$ moisture content. The last group of sample has been firstly dried at $12 \%$ moisture content and then re-saturated (one month) in water.

The universal testing machine INSTRON $5569(50 \mathrm{kN})$ was used for static bending test. The specimens were supported on a span of $490 \mathrm{~mm}$ and loaded on the radial face. The rate of loading was $1.75 \mathrm{~mm} / \mathrm{min}$. During the testing the data was captured and stored on a computer through the Instron's Merlin (Bluehill) software.

\section{Results and discussion}

Table 1 shows the MOE and MOR determined on standard small clear specimens in three moisture content conditions, namely green, dry at $12 \%$ moisture content, and re-saturated.

Table 1: Results of the density, MOE and MOR tests of Pinus ponderosa (where $\sigma$ is the standard deviation) 


\begin{tabular}{|l|l|l|l|l|l|l|}
\hline & Wood & Green & Dry & Re-saturated & $\begin{array}{l}\text { Ratio } \\
\text { dry/green }\end{array}$ & $\begin{array}{l}\text { Ratio } \\
\text { dry/re- } \\
\text { saturated }\end{array}$ \\
\hline $\begin{array}{l}\text { Density } \\
\left(\mathrm{kg} / \mathrm{m}^{3}\right) \pm 2 \sigma\end{array}$ & Juvenile & $401 \pm 14$ & $503 \pm 12$ & $587 \pm 14$ & 1.25 & 0.86 \\
\cline { 2 - 7 } & Mature & $572 \pm 39$ & $456 \pm 16$ & $668 \pm 20$ & 0.80 & 0.68 \\
\hline $\begin{array}{l}\text { MOE } \\
\left(10^{6} \mathrm{~N} / \mathrm{mm}^{2}\right) \\
\pm 2 \sigma\end{array}$ & Juvenile & $3,781 \pm 1,723$ & $5,430 \pm 2,459$ & $4,140 \pm 1,267$ & 1.44 & 1.31 \\
\cline { 2 - 7 } & Mature & $5,449 \pm 1,428$ & $7,675 \pm 2,168$ & $6,105 \pm 1,912$ & 1.41 & 1.26 \\
\hline $\begin{array}{l}\text { MOR } \\
\left(10^{3} \mathrm{~N} / \mathrm{mm}^{2}\right) \\
\pm 2 \sigma\end{array}$ & Juvenile & $25,939 \pm 8,219$ & $49,031 \pm 20,879$ & $28,626 \pm 7,624$ & 1.89 & 1.71 \\
\cline { 2 - 7 } & Mature & $35,009 \pm 8,442$ & $65,275 \pm 21,054$ & $40,710 \pm 14,156$ & 1.86 & 1.60 \\
\hline MOE/MOR & Juvenile & 0.15 & 0.11 & 0.14 & 0.73 & 0.79 \\
\cline { 2 - 7 } & Mature & 0.16 & 0.12 & 0.15 & 0.75 & 0.80 \\
\hline $\begin{array}{l}\text { MOE } / \mathbf{d e n s i t y} \\
\left(10^{6}(\mathrm{~m} / \mathrm{s})^{2}\right)\end{array}$ & Juvenile & 9 & 11 & 7 & 1.22 & 1.57 \\
\cline { 2 - 7 } & Mature & 10 & 17 & 9 & 1.70 & 1.89 \\
\hline
\end{tabular}

Data presented in Table 1 suggest the following comments:

- The modulus of elasticity MOE had the highest value for dry specimens of the mature wood and the lowest value for the specimens in green condition. Mature wood specimens had a higher MOE values than juvenile specimens. The same tendency was observed for MOR values. The re-saturated specimens showed intermediate values.

- The mature wood has higher density then the juvenile wood, as expected.

- The ratio MOE/Density is a parameter that allows comparison of wood properties of different species, as noted by Kollmann and Côté (1968). In the same time this parameter is a key value for lumber grading. In this study the highest value was measured for mature dry wood and the lowest values for re-saturated juvenile wood. This result can be attributed to the modification of wood structure induced by re-saturation and the removal of some extractible substances in water (Hillis 1987).

- The ratio for the same parameter dry/green was 1.7 for mature wood and only 1.22 for juvenile wood. The ratio dry/re-saturated varied between 1.57 for juvenile wood and 1.89 for mature wood. High ratios correspond to wood presenting high anisotropy expressed by the parameter MOE/Density. These ratios also suggest a different possible shrinkage behavior of mature and juvenile wood. The juvenile wood seems to be less anisotropic than the mature wood, probably because of the proportion of latewood in the annual ring.

- $\quad$ The ratio MOE/MOR was between 0.11 and 0.16.with higher values for mature wood.

As stated above, data on properties of Pinus ponderosa is scarce in the literature. However, data on other Pinus species used in industry have been well reported. Table 2 compiles data on selected Pinus species and the data on Pinus Ponderosa obtained from this study.

Table 2: Comparison of the properties of the Pinus ponderosa obtained from the study with properties of selected Pinus species available from the literature review

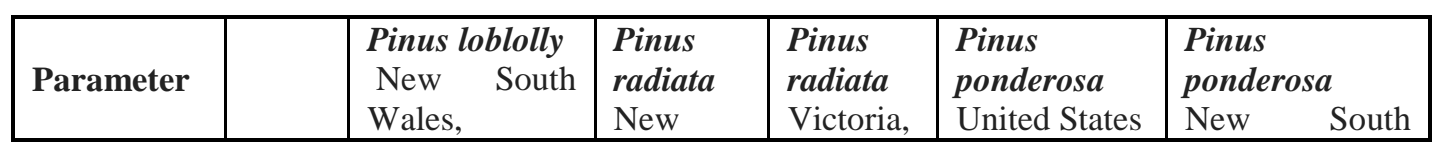




\begin{tabular}{|c|c|c|c|c|c|c|}
\hline & & Australia & Zealand & Australia & & $\begin{array}{l}\text { Wales, } \\
\text { Australia }\end{array}$ \\
\hline & & \multirow{2}{*}{$\begin{array}{ll}\text { Data } & \text { from } \\
\text { Bootle } & \\
(1986) & \end{array}$} & \multirow{2}{*}{$\begin{array}{l}\text { Data } \\
\text { from } \\
\text { Bootle } \\
(1986) \\
\end{array}$} & \multirow{2}{*}{$\begin{array}{l}\text { Data } \\
\text { from } \\
\text { Bootle } \\
(1986) \\
\end{array}$} & \multirow{2}{*}{$\begin{array}{l}\text { Data from } \\
\text { Kretschmann } \\
\text { (2010) }\end{array}$} & $\begin{array}{l}\text { Data from this } \\
\text { study }\end{array}$ \\
\hline & & & & & & \begin{tabular}{l|l}
$\begin{array}{l}\text { Mature } \\
\text { wood }\end{array}$ & $\begin{array}{l}\text { Juvenile } \\
\text { wood }\end{array}$ \\
\end{tabular} \\
\hline \multirow{2}{*}{$\begin{array}{l}\text { MOE } \\
\left(10^{6} \mathrm{~N} / \mathrm{mm}^{2}\right)\end{array}$} & Green & 5,900 & 7,300 & 8,100 & 6,900 & \begin{tabular}{|l|l|}
5,449 & 3,781 \\
\end{tabular} \\
\hline & Dry & 7,700 & 9,100 & 10,000 & 8,900 & \begin{tabular}{|l|l|}
7,675 & 5,430 \\
\end{tabular} \\
\hline \multirow{2}{*}{$\begin{array}{l}\text { MOR } \\
\left(10^{3} \mathrm{~N} / \mathrm{mm}^{2}\right)\end{array}$} & Green & 38,000 & 41,000 & 42,000 & 35,000 & \begin{tabular}{|l|l|}
35,009 & 25,939 \\
\end{tabular} \\
\hline & Dry & 77,000 & 76,000 & 81,000 & 65,000 & \begin{tabular}{|l|l|}
65,275 & 49,031 \\
\end{tabular} \\
\hline \multirow{2}{*}{$\begin{array}{l}\text { Density } \\
\left(\mathrm{kg} / \mathrm{m}^{3}\right)\end{array}$} & Green & 970 & 930 & 800 & - & 572 \\
\hline & Dry & 550 & 480 & 500 & - & 503 \\
\hline
\end{tabular}

The aptitude of Pinus ponderosa of Australian origin for industrial purposes can be roughly established by comparing average values of MOE and MOR with Pinus radiata and Pinus loblolly values from Australia and New Zealand. It is to note that the properties values of the mature Pinus ponderosa wood are relatively in the same range as the values of other Pinus spp.

\section{Conclusion}

To the author's knowledge, this study has been the first to report MOE and MOR values for juvenile and mature wood of 80 years old Australian plantation Ponderosa pine. Data presented in this report suggest that further studies are necessary to explain the mechanical behavior of Ponderosa pine wood, for the best industrial utilization of this plantation grown species.

\section{References}

ASTM D143, 2009, "Standard Test Methods for Small Clear Specimens of Timber", ASTM International, West Conshohocken, PA, 2003, DOI: 10.1520/D0143-09, www.astm.org.

Bootle KR, (1986) Wood in Australia: Types, properties and uses. McGraw Hill Book Company, Sydney, Part two: properties of species and notes on uses, Pinus ponderosa, pp. 337-338

Hillis WE, (1987) Heartwood and Tree Exudates. Wood and Fiber Science Vol.19, pp. 93-100

Kollmann FF, Côté WA, (1968) Principles of Wood Science and Technology. I - Solid Wood, Springer, New York, pp. 277-283

Kretschmann DE, (2010) Wood Handbook - Wood as an engineering material, Chapter 5: Mechanical properties of wood, General Technical Report FPL-GTR-190, Madison, US Dept. of Agriculture, pp. 4-7, http://www.fpl.fs.fed.us/documnts/fplgtr/fpl_gtr190.pdf, Accessed $15^{\text {th }}$ of March 2012.

Mack JJ, (1979) Australian methods for mechanically testing small clear specimens of timber, CSIRO Australia, Vol. 31, pp. 1 - 19

Table 1: Results of the density, MOE and MOR tests of Pinus ponderosa (where $\sigma$ is the standard deviation) 


\begin{tabular}{|c|c|c|c|c|c|c|}
\hline & Wood & Green & Dry & Re-saturated & $\begin{array}{l}\text { Ratio } \\
\text { dry/gree } \\
\text { n }\end{array}$ & $\begin{array}{l}\text { Ratio } \\
\text { dry/re- } \\
\text { saturate } \\
\text { d }\end{array}$ \\
\hline \multirow{2}{*}{$\begin{array}{l}\text { Density } \\
\left(\mathrm{kg} / \mathrm{m}^{3}\right) \pm 2 \sigma\end{array}$} & $\begin{array}{l}\text { Juvenil } \\
\mathrm{e}\end{array}$ & $401 \pm 14$ & $503 \pm 12$ & $587 \pm 14$ & 1.25 & 0.86 \\
\hline & Mature & $572 \pm 39$ & $456 \pm 16$ & $668 \pm 20$ & 0.80 & 0.68 \\
\hline \multirow{2}{*}{$\begin{array}{l}\text { MOE } \\
\left(10^{6} \mathrm{~N} / \mathrm{mm}^{2}\right) \\
\pm 2 \sigma\end{array}$} & $\begin{array}{l}\text { Juvenil } \\
\mathrm{e}\end{array}$ & $3,781 \pm 1,723$ & $5,430 \pm 2,459$ & $4,140 \pm 1,267$ & 1.44 & 1.31 \\
\hline & Mature & $5,449 \pm 1,428$ & $7,675 \pm 2,168$ & $6,105 \pm 1,912$ & 1.41 & 1.26 \\
\hline \multirow{2}{*}{$\begin{array}{l}\text { MOR } \\
\left(10^{3} \mathrm{~N} / \mathrm{mm}^{2}\right) \\
\pm 2 \sigma\end{array}$} & $\begin{array}{l}\text { Juvenil } \\
\mathrm{e}\end{array}$ & $\begin{array}{l}25,939 \pm 8,21 \\
9\end{array}$ & $\begin{array}{l}49,031 \pm 20,87 \\
9\end{array}$ & $28,626 \pm 7,624$ & 1.89 & 1.71 \\
\hline & Mature & $\begin{array}{l}35,009 \pm 8,44 \\
2\end{array}$ & $\begin{array}{l}65,275 \pm 21,05 \\
4\end{array}$ & $\begin{array}{l}40,710 \pm 14,15 \\
6\end{array}$ & 1.86 & 1.60 \\
\hline \multirow[t]{2}{*}{ MOE/MOR } & $\begin{array}{l}\text { Juvenil } \\
\mathrm{e}\end{array}$ & 0.15 & 0.11 & 0.14 & 0.73 & 0.79 \\
\hline & Mature & 0.16 & 0.12 & 0.15 & 0.75 & 0.80 \\
\hline \multirow{2}{*}{$\begin{array}{l}\text { MOE/densit } \\
\text { y }\left(10^{6}(\mathrm{~m} / \mathrm{s})^{2}\right)\end{array}$} & $\begin{array}{l}\text { Juvenil } \\
\mathrm{e}\end{array}$ & 9 & 11 & 7 & 1.22 & 1.57 \\
\hline & Mature & 10 & 17 & 9 & 1.70 & 1.89 \\
\hline
\end{tabular}

Table 2: Comparison of the properties of the Pinus ponderosa obtained from the study with properties of selected Pinus species available from the literature review

\begin{tabular}{|c|c|c|c|c|c|c|c|}
\hline \multirow[t]{3}{*}{ Parameter } & & \multirow{3}{*}{ 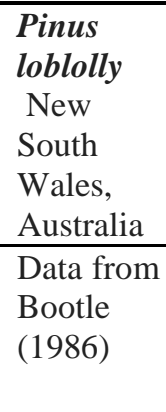 } & \multirow{3}{*}{$\begin{array}{l}\text { Pinus } \\
\text { radiata } \\
\text { New } \\
\text { Zealand } \\
\\
\text { Data } \\
\text { from } \\
\text { Bootle } \\
(1986)\end{array}$} & \multirow{3}{*}{$\begin{array}{l}\text { Pinus } \\
\text { radiata } \\
\text { Victoria, } \\
\text { Australia } \\
\\
\text { Data from } \\
\text { Bootle } \\
\text { (1986) }\end{array}$} & \multirow{3}{*}{$\begin{array}{l}\text { Pinus } \\
\text { ponderosa } \\
\text { United States } \\
\\
\begin{array}{l}\text { Data from } \\
\text { Kretschmann } \\
(2010)\end{array}\end{array}$} & \multicolumn{2}{|c|}{$\begin{array}{l}\text { Pinus ponderosa } \\
\text { New South } \\
\text { Wales, } \\
\text { Australia }\end{array}$} \\
\hline & & & & & & \multicolumn{2}{|c|}{$\begin{array}{l}\text { Data from this } \\
\text { study }\end{array}$} \\
\hline & & & & & & $\begin{array}{l}\text { Mature } \\
\text { wood }\end{array}$ & $\begin{array}{l}\text { Juvenile } \\
\text { wood }\end{array}$ \\
\hline \multirow{2}{*}{$\begin{array}{l}\text { MOE } \\
\left(10^{6} \mathrm{~N} / \mathrm{mm}^{2}\right)\end{array}$} & Green & 5,900 & 7,300 & 8,100 & 6,900 & 5,449 & 3,781 \\
\hline & Dry & 7,700 & 9,100 & 10,000 & 8,900 & 7,675 & 5,430 \\
\hline \multirow{2}{*}{$\begin{array}{l}\text { MOR } \\
\left(10^{3} \mathrm{~N} / \mathrm{mm}^{2}\right)\end{array}$} & Green & 38,000 & 41,000 & 42,000 & 35,000 & 35,009 & 25,939 \\
\hline & Dry & 77,000 & 76,000 & 81,000 & 65,000 & 65,275 & 49,031 \\
\hline \multirow{2}{*}{$\begin{array}{l}\text { Density } \\
\left(\mathrm{kg} / \mathrm{m}^{3}\right)\end{array}$} & Green & 970 & 930 & 800 & - & 572 & 401 \\
\hline & Dry & 550 & 480 & 500 & - & 456 & 503 \\
\hline
\end{tabular}




\section{University Library}

\section{- M I N E R VA}

\section{A gateway to Melbourne's research publications}

Minerva Access is the Institutional Repository of The University of Melbourne

Author/s:

Daian, M;Bucur, V;Ozarska, B;Daian, G

Title:

Static strength characteristics (MOR and MOE) of Australian Pinus ponderosa wood from plantation: a comparison of green, dry and re-wet specimens: a technical note

Date:

2012-12-01

\section{Citation:}

Daian, M., Bucur, V., Ozarska, B. \& Daian, G. (2012). Static strength characteristics (MOR and MOE) of Australian Pinus ponderosa wood from plantation: a comparison of green, dry and re-wet specimens: a technical note. JOURNAL OF THE INDIAN ACADEMY OF WOOD SCIENCE, 9 (2), pp.140-142. https://doi.org/10.1007/s13196-012-0080-5.

Persistent Link:

http://hdl.handle.net/11343/282688 